\title{
Why Do Local Foodscapes Matter in Building Tourist Trust and Loyalty?
}

\author{
Jae-Jang Yang ${ }^{1,2}$, Rajesh Iyer ${ }^{3}$ and Yong-Ki Lee ${ }^{1, *(1)}$ \\ 1 School of Business, Sejong University, Seoul 05006, Korea; doublej@sejong.ac.kr \\ 2 Graduate School of eMA, Sejong University, Seoul 05006, Korea \\ 3 Department of Marketing, Bradley University, Peoria, IL 61625, USA; riyer@fsmail.bradley.edu \\ * Correspondence: yongki2@sejong.ac.kr; Tel.: +82-2-3408-3158
}

\section{check for}

updates

Citation: Yang, J.-J.; Iyer, R.; Lee, Y.-K. Why Do Local Foodscapes Matter in Building Tourist Trust and Loyalty? Sustainability 2022, 14, 2029. https:// doi.org/10.3390/su14042029

Academic Editor: Jeong-Gil Choi

Received: 5 January 2022

Accepted: 7 February 2022

Published: 10 February 2022

Publisher's Note: MDPI stays neutral with regard to jurisdictional claims in published maps and institutional affiliations.

Copyright: (c) 2022 by the authors. Licensee MDPI, Basel, Switzerland. This article is an open access article distributed under the terms and conditions of the Creative Commons Attribution (CC BY) license (https:// creativecommons.org/licenses/by/ $4.0 /)$.

\begin{abstract}
This study examines local foodscapes and their dimensions, namely, eco-friendly environment, tradition, infrastructure, accessibility, and price/value, on trust in a store and local food, which in turn impacts loyalty and identified full mediating roles of trust in a store and local food in the relationship between local foodscapes and loyalty. Data were collected from visitors (tourists) who had experienced local foods over the last three months and were analyzed with SmartPLS 3.3.3. The findings show that the dimensions of price/value and eco-friendly environment influence trust in the local store, whereas the history or the tradition along with the eco-friendly environment has an impact on local food consumption-both the local store and the local food influence the level of loyalty among tourists. Implications for theory and practice are discussed within the context of local foodscapes.
\end{abstract}

Keywords: local food; local foodscape; trust; loyalty; SmartPLS

\section{Introduction}

As local foods contribute to the growth and differentiation of the local economy, local food tourism is attracting attention from scholars and practitioners. Local foods help enhance the travel experience [1]. Studies on local foods have primarily been being conducted in the areas of destination foodscapes [2], local food consumption [3,4], food/gastronomic experiences in tourism [5-7]. Unique local foods serve as motives to stimulate tourists' travel [8] and play crucial roles in affective responses, such as emotions [9], perceived value $[10,11]$, trust [12], attachment $[13,14]$, satisfaction $[9,12]$ during travel, and behavioral responses, such as revisit intention and word-of-mouth [10] after travel.

Eighty percent of the travelers research food and drink options while traveling to a new destination (World Food Travel Association 2021) [15]. According to Technavio, a market research firm out of the UK, the compound annual growth rate for food tourism is expected to increase by $9 \%$ between 2019-2023. Food tourists spend on average, $25 \%$ of their travel budget on food and beverages (World Food Travel Association 2021) [15]. Within Korea, the geographical location of the study, local food contributes to increasing the image and income of the local community by providing unique local products. The local food direct stores in Korea started with 21 stores in 2013 and increased to 660 stores in 2021. Meanwhile, the related sales increased from KRW 19.3 billion to KRW 460.4 billion in 2020 (http:/ / www.agrinet.co.kr/news/articleView.html?idxno=304016, accessed on 15 November 2021). The local food in Korea is one of the primary reasons why foreign tourists have engaged in choosing Korea as a tourist destination [16].

Local food marketing should be managed and involved in rural development strategy [17] because tourist satisfaction and responses are influenced in "local foodscapes", where local tour experiences are produced and consumed. Based on Lee et al. [9], this is a basic question or task that needs to be solved by managers of local tourism. Local foodscapes could play a pivotal role in building tourist-based places or local equity because 
tourists spend money on experiencing a variety of local attractions as well as buying local foods. Research has found that local foods can enhance the image of a destination because it represents national, regional, and personal identities [18-20]. Rong-Da Liang et al. [21] found that food and beverage expenditure increases tourists' revisit intention and favorable word-of-mouth. Despite the significance of local foodscapes, very little is known about successful local foodscapes and whether they affect local food stores and trust, which, in turn, increase tourist loyalty. This study aims to close that gap in the literature.

This study serves multiple purposes. It addresses the factors or dimensions of local foodscapes. It answers the call for studies to be conducted on food consumption as it is an important component in the field of tourism and hospitality (e.g., [1]) by trying to identify the components of the local foodscapes. To the best of our knowledge, no research has addressed the factors of local foodscapes and their effect on trust and loyalty in the tourism context. Second, the current study contributes to the literature by integrating the cue-consistency and trust-transfer theories. This study, based on cue-consistency theory [22] and trust-transfer theory $[23,24]$, suggests that local foodscapes, which represent the overall image of tourist destination, can be the source of trust for tourists who are unfamiliar with the destination and are positively associated with trust in local foods stores and local foods. Lastly, this study concerns the treatment of local store trust and local food trust as mediators. In this study, the mediating effect is a valuable step forward to test the effects of local foodscapes on local foods stores and local foods. According to some studies [24-26], researchers view local foodscapes perceived by consumers as an original source of tourist trust about local foodscapes, embodying consumer trust in stores and foods and leading to loyalty. This view illustrates the process of generating and transferring trust by showing the evidence by which tourist perception or direct experience of local foodscapes leads to trust $[24,25,27]$. Our paper is organized as follows: we first discuss the relevant literature and then propose the hypotheses for the study. We follow this by explaining the methodology that we use to arrive at the results. We conclude the paper by addressing the implications and limitations of the study.

\section{Literature Review}

\subsection{Local Foodscapes and Local Food Consumption}

Local foodscapes as destination cues play crucial roles in influencing tourists' experience $[9,28]$ or destination quality [29] within a local destination based on environmental psychology. The question here is which factors should be considered when evaluating a destination. In order to accomplish this, researchers have suggested starting with the SERVICESCAPE by Bitner [30] and presenting the physical environment or cues as a destination clue in the context of retail [31], destination [32], restaurant [29], and festival situations [9]. As Bitner [30] noted, SERVICESCAPE is the environment built or physical surroundings made by humans and can be regarded as a place where people visiting a place and organized environments interact [31]. Based on this, local FOODSCAPES should be viewed as physical or environmental cues of a destination where interactions between the organized places visited and the tourists who purchase local food. These cues can vary across different types of service contexts and destinations. Studies similar to local foodscapes have included different subdimensions to capture the experience. Studies [32-34] on various service contexts and destinations have included an eco-friendly environment, tradition, infrastructure, accessibility, and price/value to measure the foodscapes. To measure the local foodscapes, we decided to include cognitive cues or images that are directly observable, descriptive, and measurable. We decided to include these in our measure of the local foodscapes $[34,35]$.

As the interest in food tourism using food and the demand for tourism increase, the eco-friendliness or sustainability of areas producing local food is regarded as an important factor in evaluating local foodscapes [31]. It allows the local or regional community to have a local food system that produces local specialties on a small scale, using natural ingredients compared to global food. The transmission of the natural image that food is 
growing naturally ensures that the food production process is controlled and produced with natural attributes [36-38].

Regions with a unique history, traditions, and eno-gastronomic heritage influence the success of the niche market for food tourism [17]. Tourists are psychologically and physiologically assimilated to local values by purchasing or consuming natural, traditional, or farm products [39]. This indicates that food culture plays an important role in commercializing tradition [40] and allows the regional marketer to build consuming heritage branding [41]. Traditional food refers to food that has been recognized by the community [42]. Local foods with traditional characteristics or images are perceived as high-quality $[43,44]$, sustainable foods $[45,46]$ that satisfy consumers' desire for cultural identity and ethnocentrism.

In order to meet and promote consumer demand, it is necessary to establish infrastructure, such as local food stores or shopping centers and restaurants for local food production sites [47]. The infrastructure of a well-established local food production area can increase customer trust in food [48].

On the other hand, local food is generally sold locally, so access to local food places is very important to tourists. Accessibility is the ease of access from a customer's place of departure to a designated destination [49] and refers to the proximity of a customer's place of residence to the place of food purchase [50,51]. In addition, accessibility is the convenience of movement based on public transportation and road networks [52]. Developing accessibility of local food reduces the temporal and physical distance between food production and consumption [53].

Lastly, the price/value concept is regarded as a monetary sacrifice or product quality for a customer to obtain a product [54] and affects customer trust and behavior [55]. Value for money also can influence service quality perception [35] of local food stores and local food. In general, organic food is perceived to be more expensive than non-organic food [56], making it an obstacle to consumption [57] as well as reducing purchase intention [58]. Therefore, local food marketers should check whether the price of local food is perceived appropriately, fairly, and reasonably compared to other general products, and identify the impact on consumer trust because local food is a medium that allows the exchange of trust between tourists and buyers [59], indicating local food delivers high quality and trust to consumers.

\subsection{Relationship between Local Foodscapes and Trust}

Consistent with prior research [60] that incorporates consumers as agents in the development of local food projects, we posit that local foodscapes play an important role in the formation of trust in the local stores along with trust in the local food. This indicates that the locale in which local foods are produced, or local foods, is associated with the tourist, resulting in the creation of the tourist's local food experience [61], which in turn leads to a tourist's overall impression of a local food destination or place. Accordingly, local foodscapes as a holistic perception play critical roles in building tourists' trust in local food destinations and food.

Local food is perceived as high-quality food produced by local artisans with history and tradition. However, local food is produced on a smaller scale compared to global brand food, so tourists have a high level of uncertainty and safety concerns that may reduce trust in local foodscapes, including local food. Therefore, it becomes important to understand how to manage the local food system in a way that lessens the risks or improves safety. However, research on trust in food tourism is still relatively limited compared to other retail settings. Based on the literature on destination image [62,63], local foodscapes act as direct antecedents of trust. In addition, Su et al. [52] found that a World Heritage Site with a positive image reduces tourists' uncertainty and perceived risk, thus resulting in a higher level of trust toward destination service providers. Roy et al. [64] argued that local food farmers need to develop trust-based relationships to make it easier for buyers to access the local food market. 
Trust in local food is essential because tourists consume or purchase local food without complete information on the quality, safety, and sustainable production of local food [65]. When arriving at a local food tourist destination, tourists build trust in local food stores and local food through the overall impression of the various factors that make up local foodscapes. In general, trust in food is formed through ongoing social dynamics between different actors and institutions involved in the process of production, distribution, control, and consumption of food [66,67]. However, trust in local food will be formed through the ongoing social dynamics between different actors and local food outlets in local foodscapes. This means that, unlike general food, trust in local food is shaped through interactions such as product information acquired at stores where local food is sold, information shared through salespeople, etc. Therefore, similar to the study of Al-Ansi and Han [12], trust is embodied as the confidence and certainty that tourists have acquired about local food stores and local food as an important element of exchange. Thus, we proposed the following hypotheses.

Hypothesis 1 (H1). Local foodscapes have a positive influence on trust in local food stores.

Hypothesis 1-1 (H1-1). An eco-friendly environment has a positive influence on trust in local food stores.

Hypothesis 1-2 (H1-2). Tradition has a positive influence on trust in local food stores.

Hypothesis 1-3 (H1-3). Infrastructure has a positive influence on trust in local food stores.

Hypothesis 1-4 (H1-4). Accessibility has a positive influence on trust in local food stores.

Hypothesis 1-5 (H1-5). Price/value has a positive influence on trust in local food stores.

Hypothesis 2 (H2). Local foodscapes have a positive influence on trust in local food.

Hypothesis 2-1 (H2-1). An eco-friendly environment has a positive influence on trust in local food.

Hypothesis 2-2 (H2-2). Tradition has a positive influence on trust in local food.

Hypothesis 2-3 (H2-3). Infrastructure has a positive influence on trust in local food.

Hypothesis 2-4 (H2-4). Accessibility has a positive influence on trust in local food.

Hypothesis 2-5 (H2-5). Price/value has a positive influence on trust in local food.

\subsection{The Linkage between Local Food Stores and Local Food and Trust Transfer Theory}

We posit that trust in local food stores is an antecedent of trust in local food. This argument is based on the theory of trust transfer that the source of trust can be transferred to another object (or person) with no direct experience of the trustor [23,24]. Research has $[24,26,68]$ shown that trust generated in a place or institution can be transferred to a product or service. For example, Doney and Cannon [69] showed that customer trust in a store can be transferred to trust in the products the store sells. Xiao et al. [70] showed that trust in the $\mathrm{O} 2 \mathrm{O}$ platform is transferred to trust in merchants. Liu et al. [71] also found that consumer-to-marketer (C2M) trust has a positive effect on brand trust in on social media brand community context. In addition, Konuk [68] found that trust in manufacturer brands influences trust in private brands. Accordingly, we expect that trust in local food stores stemming from local foodscapes can be transferred to trust in local food.

Hypothesis 3 (H3). Trust in local food stores has a positive influence on trust in local food. 


\subsection{The Relationship between Trust and Loyalty}

Trust is the certainty and confidence of an exchange partner [72] and is defined as the belief that the exchange partner will perform well in the business relationship [73]. Trust in local food stores and local food can play critical roles, leading to customer loyalty. The tourists believe that their expectations and desires for a local food experience will be met [74] by local food stores and local food and that local food marketers will deliver on their promises [75]. In the context of local food destinations, since trust reduces the uncertainty in the environment in which consumers feel vulnerable by relying on trusted brands [76], it strengthens consumers' repetitive buying behavior and induces brand attitude and buying behavior in the future or increases loyalty [77]. Accordingly, numerous studies found that trust plays a critical role in increasing loyalty (buying intention and word-of-mouth) or buying behavior. Konuk [78] found that store trust influences store loyalty. Chaudhuri and Holbrook [79] found that brand trust is related to brand loyalty. Meanwhile, Xiao et al. [70] showed that trust in the O2O platform and merchants influence repurchase intention. In addition, Konuk [68] found that trust in manufacturer brands and trust in private brands result in a higher willingness to buy. Based on this, we hypothesize that trust in local food stores and local food increase loyalty.

Hypothesis 4 (H4). Trust in local food store has a positive influence on loyalty.

Hypothesis 5 (H5). Trust in local food has a positive influence on loyalty.

\section{Methodology}

\subsection{Sampling and Data Collection}

Data were collected using an online survey questionnaire from respondents who had experienced local foods over the last 3 months through a market research company. An online survey has the advantages of low management cost, a short period of time, and easy to obtain many samples [8]. To ensure the content validity of the measures, we tried to use existing measures wherever possible. We sought the help of experts with translation and back translation (using separate experts for each aspect that we twice reviewed by two bilingual researchers fluent in English and Korean). We approached experts to review the questionnaire and assess the ambiguity and readability of the items in the study [80]. We made changes to the questionnaire as we received feedback on every stage of the process.

The online survey company sent e-mails and text messages to a total of 2100 panelists with local food tourism experience. A total of 291 panelists responded. Of the collected data, 11 responses included incomplete data and were deleted from the analyses. We had a final sample of 280 usable responses. The sample size is more than 5 times per variable, which is sufficient for structural models [81-83].

The sample for our study was evenly distributed in terms of gender. Fifty-five percent of our respondents reported that they were married. In terms of age, $36.8 \%$ of the respondents were in the age group of the 30s, followed by those in their $40 \mathrm{~s}(28.2 \%), 20 \mathrm{~s}(23.6 \%)$, and 50 s or older $(11.4 \%)$. More than half of the sample were college-educated $(55.4 \%)$. In terms of employment, $48.2 \%$ of the respondents reported that they held some official post. Finally, 31.1\% of the respondents reported a monthly household income of 200-400 million won (USD1 = approximately 1000 Korean won), followed by $400-600$ million $(28.9 \%)$ and 600-800 million (15.7\%) (see Table 1). 
Table 1. Demographic Characteristics $(n=280)$.

\begin{tabular}{|c|c|c|c|}
\hline Category & & $n$ & $\%$ \\
\hline \multirow[t]{2}{*}{ Gender } & Male & 144 & 51.4 \\
\hline & Female & 136 & 48.6 \\
\hline \multirow[t]{2}{*}{ Marital status } & Single & 126 & 45.0 \\
\hline & Married & 154 & 55.0 \\
\hline \multirow[t]{4}{*}{ Age } & $20-29$ & 66 & 23.6 \\
\hline & $30-39$ & 103 & 36.8 \\
\hline & $40-49$ & 79 & 28.2 \\
\hline & $50-59$ & 32 & 11.4 \\
\hline \multirow[t]{4}{*}{ Educational level } & Below high school & 41 & 14.6 \\
\hline & Undergraduate & 54 & 19.3 \\
\hline & Four years university & 155 & 55.4 \\
\hline & Graduate school & 30 & 10.7 \\
\hline \multirow[t]{6}{*}{ Monthly incomes } & Less than 1 million won ${ }^{\#}$ & 9 & 3.2 \\
\hline & 1 million-Less than 2 million won & 26 & 9.3 \\
\hline & 2 million-Less than 4 million won & 87 & 31.1 \\
\hline & 4 million-Less than 6 million won & 81 & 28.9 \\
\hline & 6 million-Less than 8 million won & 44 & 15.7 \\
\hline & More than 8 million won & 33 & 11.8 \\
\hline \multirow[t]{7}{*}{ Job } & Officer & 135 & 48.2 \\
\hline & Student & 24 & 8.6 \\
\hline & Housewife & 24 & 8.6 \\
\hline & Professional & 38 & 13.6 \\
\hline & Technical & 15 & 5.4 \\
\hline & Service & 23 & 8.2 \\
\hline & Other & 21 & 7.5 \\
\hline
\end{tabular}

\# USD1 = approximately 1000 Korean won.

\subsection{Construct Operationalization}

All items were adopted/modified from established scales in the literature and measured using items utilized in prior studies using 7-point Likert scales anchored by " $1=$ strongly disagree" and "7 = strongly agree". Local foodscapes and their dimensions, eco-friendly environment, tradition, infrastructure, accessibility, and price/value, were measured by modified items used by previous studies $[32,33,35]$. Trust in the local store and trust in local food were measured by modifying items used by Xie et al. [84]. Finally, loyalty was measured using modifying items used by Kim et al. [85] and Lee et al. [86].

\section{Results}

\subsection{Measurement Model}

In order to assess validity and reliability, measurement model and structural model analyses were conducted using the SmartPLS 3.3.3 program. As shown in Table 2, the average variance extracted (AVE) and factor loadings exceeded 0.5 , indicating convergent validity was confirmed. Next, the values of composite reliabilities $(\mathrm{CR})$ were larger than 0.7 , so (internal consistency) reliability was established. In addition, the square root of AVE in each construct was larger than other correlation values among the constructs (see Table 3). Finally, the heterotrait-monotrait (HTMT) ratio of correlations $[87,88]$ values was under 0.900 (see Table 4). Thus, discriminant validity was well established. In addition, normality was checked using values of kurtosis and skewness. As shown in Table 2, normality was not problematic because the values of skewness and kurtosis were less than $|2.0|$ and $|9.0|$, respectively [89]. 
Table 2. Measurement Model.

\begin{tabular}{|c|c|c|c|c|c|}
\hline Items & $\begin{array}{c}\text { Standardized } \\
\text { Factor Loadings }\end{array}$ & Kurtosis & Skewness & Mean & SD \\
\hline \multicolumn{6}{|l|}{$\begin{array}{l}\text { Eco-friendly environment } \\
\left(\mathrm{CR}^{\mathrm{a}}=0.911, \mathrm{AVE}^{\mathrm{b}}=0.673, \text { Cronbach } \alpha=0.878\right)\end{array}$} \\
\hline Safe and secure environment & 0.788 & 1.279 & 0.353 & 4.70 & 0.98 \\
\hline Clean and tidy environment & 0.838 & 5.186 & 1.038 & 4.84 & 1.01 \\
\hline Hygienic local people & 0.808 & 0.403 & -0.140 & 4.67 & 1.03 \\
\hline Tranquil and restful atmosphere & 0.841 & 0.441 & -0.328 & 4.73 & 0.95 \\
\hline Clean air & 0.826 & 2.017 & -0.633 & 4.82 & 1.05 \\
\hline \multicolumn{6}{|l|}{ Tradition } \\
\hline \multicolumn{6}{|l|}{$(\mathrm{CR}=0.903, \mathrm{AVE}=0.757$, Cronbach $\alpha=0.839)$} \\
\hline Most produced local food & 0.852 & 4.124 & 0.670 & 4.89 & 1.05 \\
\hline Local food with a long story & 0.862 & 0.571 & -0.238 & 4.93 & 0.98 \\
\hline Most known local food & 0.895 & 0.436 & 0.157 & 5.00 & 1.091 \\
\hline \multicolumn{6}{|l|}{ Infrastructure } \\
\hline \multicolumn{6}{|l|}{$(\mathrm{CR}=0.923, \mathrm{AVE}=0.800$, Cronbach $\alpha=0.873)$} \\
\hline Wide selection of restaurants/cuisine & 0.870 & 0.784 & -0.248 & 4.59 & 1.14 \\
\hline Various local food stores & 0.912 & 0.639 & 0.220 & 4.47 & 1.09 \\
\hline Wide choice of local foods in the store & 0.899 & 1.808 & -0.229 & 4.46 & 1.09 \\
\hline \multicolumn{6}{|l|}{ Accessibility } \\
\hline \multicolumn{6}{|l|}{$(\mathrm{CR}=0.904, \mathrm{AVE}=0.702$, Cronbach $\alpha=0.859)$} \\
\hline $\begin{array}{l}\text { Well communicated traffic flow and parking } \\
\text { information }\end{array}$ & 0.845 & 0.665 & 0.110 & 4.42 & 1.03 \\
\hline Available parking downtown & 0.849 & 1.301 & -0.070 & 4.45 & 1.08 \\
\hline Easy access to the area & 0.854 & 1.069 & 0.325 & 4.52 & 1.14 \\
\hline Easy-to-use and affordable trolley system & 0.804 & 0.676 & -0.366 & 4.29 & 1.23 \\
\hline \multicolumn{6}{|l|}{ 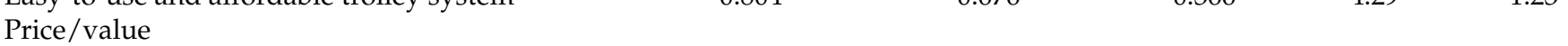 } \\
\hline \multicolumn{6}{|l|}{$(\mathrm{CR}=0.904, \mathrm{AVE}=0.701$, Cronbach $\alpha=0.859)$} \\
\hline Reasonable price for local food & 0.830 & 1.092 & 0.372 & 4.21 & 1.13 \\
\hline Good value for money & 0.862 & 1.004 & -0.312 & 4.48 & 1.01 \\
\hline Fair price for local foods & 0.860 & 0.532 & 0.057 & 4.35 & 1.03 \\
\hline Good bargain shopping & 0.796 & 0.441 & -0.267 & 4.19 & 1.15 \\
\hline \multicolumn{6}{|l|}{ Store trust } \\
\hline \multicolumn{6}{|l|}{$(\mathrm{CR}=0.946, \mathrm{AVE}=0.815$, Cronbach $\alpha=0.924)$} \\
\hline I trust this local food store & 0.897 & 0.935 & -0.046 & 4.70 & 1.01 \\
\hline The local food store is reliable & 0.912 & 1.183 & -0.243 & 4.71 & 1.09 \\
\hline The local food store is honest & 0.902 & 1.776 & 0.067 & 4.64 & 1.06 \\
\hline The local food store is dependable & 0.900 & 0.512 & 0.062 & 4.59 & 1.05 \\
\hline \multicolumn{6}{|l|}{ Local food trust } \\
\hline \multicolumn{6}{|l|}{$(\mathrm{CR}=0.922, \mathrm{AVE}=0.748$, Cronbach $\alpha=0.887)$} \\
\hline I trust this local food. & 0.845 & 7.991 & -1.128 & 4.92 & 0.95 \\
\hline The local food is reliable & 0.901 & 1.103 & -0.144 & 4.92 & 0.96 \\
\hline The local food is honest & 0.869 & 0.216 & 0.288 & 4.78 & 1.02 \\
\hline The local food is dependable & 0.844 & 0.218 & 0.284 & 4.91 & 0.93 \\
\hline \multicolumn{6}{|l|}{ Loyalty } \\
\hline \multicolumn{6}{|l|}{$(\mathrm{CR}=0.939, \mathrm{AVE}=0.794$, Cronbach $\alpha=0.913)$} \\
\hline I will buy the local food again the next time & 0.890 & 3.917 & 0.530 & 5.01 & 1.00 \\
\hline $\begin{array}{l}\text { I think I will buy the local food again in the } \\
\text { future }\end{array}$ & 0.894 & 0.915 & -0.293 & 4.93 & 1.05 \\
\hline $\begin{array}{l}\text { I will make efforts to buy this local food more } \\
\text { actively in the future }\end{array}$ & 0.900 & -0.027 & 0.119 & 4.71 & 1.13 \\
\hline $\begin{array}{l}\text { I would recommend this local food to my friends } \\
\text { and neighbors }\end{array}$ & 0.879 & 0.200 & -0.431 & 4.68 & 1.12 \\
\hline
\end{tabular}

\footnotetext{
${ }^{\mathrm{a}} \mathrm{CR}$ (Composite Reliability), ${ }^{\mathrm{b}}$ AVE (Average Variance Extracted).
} 
Table 3. Fornell-Larcker Criterion and Correlation Matrix.

\begin{tabular}{|c|c|c|c|c|c|c|c|c|}
\hline & 1 & 2 & 3 & 4 & 5 & 6 & 7 & 8 \\
\hline 1. Eco-friendly environment & 0.820 & & & & & & & \\
\hline 2. Tradition & $0.687^{\#}$ & 0.870 & & & & & & \\
\hline 3. Infrastructure & 0.598 & 0.502 & 0.894 & & & & & \\
\hline 4. Accessibility & 0.633 & 0.531 & 0.594 & 0.838 & & & & \\
\hline 5. Price/value & 0.635 & 0.440 & 0.627 & 0.716 & 0.837 & & & \\
\hline 6. Store trust & 0.689 & 0.524 & 0.570 & 0.571 & 0.640 & 0.903 & & \\
\hline 7. Local food trust & 0.746 & 0.606 & 0.561 & 0.540 & 0.573 & 0.779 & 0.865 & \\
\hline 8. Loyalty & 0.666 & 0.548 & 0.538 & 0.525 & 0.583 & 0.753 & 0.779 & 0.891 \\
\hline Mean & 4.753 & 4.940 & 4.506 & 4.421 & 4.305 & 4.661 & 4.880 & 4.835 \\
\hline SD & 0.823 & 0.904 & 0.987 & 0.940 & 0.905 & 0.951 & 0.836 & 0.958 \\
\hline
\end{tabular}

\# All coefficients are significant at $p<0.01$. Note: Bold numbers indicate the square root of AVE.

Table 4. Heterotrait-Monotrait Ratio (HTMT).

\begin{tabular}{lccccccc}
\hline & $\mathbf{1}$ & $\mathbf{2}$ & $\mathbf{3}$ & $\mathbf{4}$ & $\mathbf{5}$ & $\mathbf{6}$ & $\mathbf{7}$ \\
\hline 1. Eco-friendly environment & & & & & & & \\
2. Tradition & 0.798 & & & & & & \\
3. Infrastructure & 0.680 & 0.580 & & & & \\
4. Accessibility & 0.724 & 0.608 & 0.684 & & & \\
5. Price/value & 0.723 & 0.505 & 0.722 & 0.840 & & & \\
6. Store trust & 0.763 & 0.591 & 0.633 & 0.637 & 0.710 & & \\
7. Local food trust & 0.844 & 0.701 & 0.634 & 0.613 & 0.643 & 0.860 & \\
8. Loyalty & 0.744 & 0.624 & 0.601 & 0.590 & 0.648 & 0.819 & 0.865 \\
\hline
\end{tabular}

\subsection{Testing for Common Method Bias}

To reduce common method bias (CMB), we used procedural and statistical approaches suggested by the authors of [90]. Procedurally, we first informed the participant about the research purpose of the study and provided them with instructions to help increase the probability of response accuracy [91]. Then, we removed ambiguous items which were difficult for the respondents to understand or interpret in the pre-test stage of the questionnaire development. Finally, we changed the order sequence of the variables (both independent and dependent) and did not measure in the order presented in the proposed model and provided page breaks in the online questionnaire. Next, in terms of the statistical approach, the CMB bias was assessed using the variance inflation factor (VIF) value [92]. The common method bias was not a problem because the VIF value was lower than 3.3 $(\mathrm{VIF}=1.948-3.026)$.

\subsection{Assessment of Structural Model}

We assessed the structural model using the following criteria with SmartPLS 3.3.3 [93-95] (see Figure 1). PLS is a suitable analytical method for maximizing the explained variance of endogenous variables, namely, or for research contexts that are data-rich and grounded in theory [96]. PLS-SEM provides a high degree of statistical power compared to covariancebased SEM [97], which means that PLS-SEM is more likely to determine relationships as significant when they are, in fact, existent in the population [98]. This characteristic of the method is useful for testing a model that introduces a new latent variable [97]. This study presents antecedents of store trust and local food trust and their relationship to loyalty. While an argument can be made that trust and loyalty are commonly addressed concepts, the antecedents of store trust and local food trust, such as tradition and infrastructure, are novel latent concepts that motivated us to use PLS-SEM for hypothesis testing. First, the data have no multicollinearity problem among exogenous constructs because the values of VIF were lower than 3.1. Second, $\mathrm{R}^{2}$ values of the dependent variables were above moderate ( 0.67 = substantial, $0.33=$ moderate, $0.19=$ weak, [99] $)$ because the predictive power of the model ranged from 0.557 to 0.701 . Third, the prediction relevance of the model 
was achieved because the values of the Stone-Gesser test $\left(\mathrm{Q}^{2}\right)$ ranged from 0.446 to 0.522 , indicating the prediction relevance of the model was achieved. Finally, the structural model was considered a good fit because the value of standardized root mean square residual (SRMR) (0.054) was lower than the cut-off threshold of 0.08 [100].

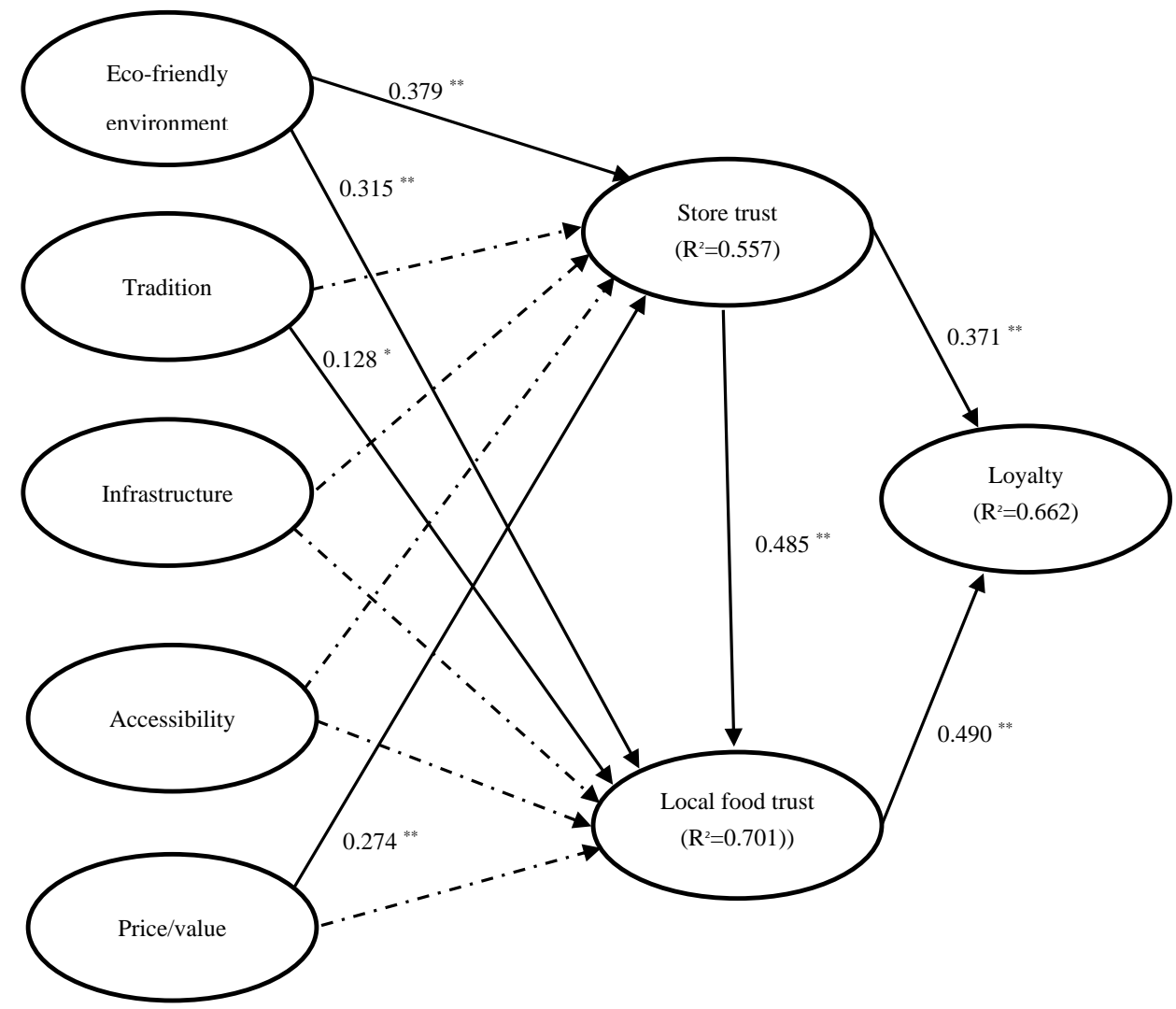

Figure 1. Estimates of the model (PLS). ${ }^{* *} p<0.01,{ }^{*} p<0.05$. Solid lines: significant paths. Dotted lines: non-significant paths.

\subsection{Hypotheses Testing}

H1a-H1e look at the direct relationship between local foodscapes and store trust. We found support for H1a, where the eco-friendly environment significantly affects the trust in the local store $(\beta=0.379, t=4.242, p<0.001)$, and H1e, where the price/value $(\beta=0.274$, $t=4.015, p<0.01)$ significantly affects trust in the local store. However, none of the other dimensions of the local foodscapes had an impact on trust in the local food store (see Table 5).

Similarly, we tested for the direct relationship between the local foodscapes and trust in the local food. We found support for the dimension of eco-friendly environment and trust in the local food ( $\mathrm{H} 2-1: \beta=0.315, t=4.625, p<0.001)$ and between tradition and trust in the local food (H2-2: $\beta=0.128, t=2.068, p<0.05)$. None of the other dimensions of the local foodscape had a significant impact on trust in local food consumption.

We further looked at the relationship between trust in the local store and trust in the local food. We found support for $\mathrm{H} 3(\beta=0.485, \mathrm{t}=8.056, p<0.001)$. We also looked at the relationship between trust in the local store and loyalty (H4: $\beta=0.371, t=5.573$, $p<0.001)$. Store trust significantly affects local food trust and loyalty. Thus, H3 and H4 were supported. Finally, we also found support for the relationship between trust in local food and loyalty (H5: $\beta=0.490, t=7.632, p<0.001$ ). H5 was supported (see Table 5). 
Table 5. Structural Estimates (PLS).

\begin{tabular}{|c|c|c|c|c|c|c|}
\hline & Paths & Estimate & $t$-Value & $p$ & $\mathbf{f}^{2}{ }_{2}$ & Support \\
\hline H1-1 & Eco-friendly environment $\rightarrow$ Store trust & 0.379 & 4.242 & $0.000 * *$ & 0.120 & Yes \\
\hline $\mathrm{H} 1-2$ & Tradition $\rightarrow$ Store trust & 0.068 & 1.105 & 0.269 & 0.005 & No \\
\hline H1-3 & Infrastructure $\rightarrow$ Store trust & 0.122 & 1.582 & 0.114 & 0.017 & No \\
\hline $\mathrm{H} 1-4$ & Accessibility $\rightarrow$ Store trust & 0.026 & 0.381 & 0.703 & 0.001 & No \\
\hline H1-5 & Price/value $\rightarrow$ Store trust & 0.274 & 4.015 & $0.000 * *$ & 0.067 & Yes \\
\hline $\mathrm{H} 2-1$ & Eco-friendly environment $\rightarrow$ Local food trust & 0.315 & 4.625 & $0.000 * *$ & 0.110 & Yes \\
\hline $\mathrm{H} 2-2$ & Tradition $\rightarrow$ Local food trust & 0.128 & 2.068 & $0.039 *$ & 0.027 & Yes \\
\hline $\mathrm{H} 2-3$ & Infrastructure $\rightarrow$ Local food trust & 0.055 & 0.885 & 0.376 & 0.005 & No \\
\hline $\mathrm{H} 2-4$ & Accessibility $\rightarrow$ Local food trust & -0.034 & 0.636 & 0.525 & 0.002 & No \\
\hline $\mathrm{H} 2-5$ & Price/value $\rightarrow$ Local food trust & -0.004 & 0.060 & 0.952 & 0.000 & No \\
\hline H3 & Store trust $\rightarrow$ Local food trust & 0.485 & 8.056 & $0.000 * *$ & 0.349 & Yes \\
\hline $\mathrm{H} 4$ & Store trust $\rightarrow$ Loyalty & 0.371 & 5.573 & $0.000 * *$ & 0.160 & Yes \\
\hline H5 & Local food trust $\rightarrow$ Loyalty & 0.490 & 7.632 & $0.000 * *$ & 0.280 & Yes \\
\hline & & & $R^{2}$ & & \multicolumn{2}{|c|}{$\mathrm{Q}^{2}$} \\
\hline & Store trust & & 0.557 & & \multicolumn{2}{|c|}{0.446} \\
\hline & Local food trust & & 0.701 & & \multicolumn{2}{|c|}{0.516} \\
\hline & Loyalty & & 0.662 & & \multicolumn{2}{|c|}{0.522} \\
\hline
\end{tabular}

${ }^{* *} p<0.01, * p<0.05$.

\subsection{Analysis of Effect Size}

We examined the relative effect of the independent variable on the dependent variable using the effect size $\left(\mathrm{f}^{2}\right)$ (Chin, 1998), where $0.35,0.15$, and 0.02 represent large, medium, and small, respectively (Cohen, 1988). As shown in Table 5, the effect size of eco-friendly environment (0.120) and price/value (0.067) on store trust were small, respectively. Furthermore, the effect size of eco-friendly environment $(0.110)$ and tradition $(0.027)$ on local food trust were small, respectively. In addition, store trust had a moderate effect size on local food trust (0.349) and loyalty (0.160), respectively. Finally, the effect size of local food trust on loyalty was medium (0.280).

Additionally, we tested the mediating roles of local food stores and local food between local foodscapes and loyalty. The findings of our study showed that local foodscapes did not have a significant effect on loyalty. Therefore, store and local food trust play full mediating roles in the relationship between local foodscapes and loyalty.

\section{Conclusions and Implications}

This study identified five dimensions-eco-friendly environment, tradition, infrastructure, accessibility, and price/value - that represented local foodscapes and examined how these cues influence trust in a store and local food and, in turn, loyalty. The findings indicated that local foodscapes marketers should establish a resource allocation strategy according to the relative importance of the five local foodscapes cues to increase trust and increase loyalty. This study also suggests that trust in local food stores and local food plays a crucial role in understanding customer loyalty, such as purchase behavior and word-of-mouth communication.

\subsection{Theoretical Implications}

The current study contributes to the literature on environmental cues. First, this study used the term local foodscapes in a similar way to the festivalscapes study [9] and suggested the cues to be considered for evaluating local food places. Based on a cue-consistency theory [22], this study supports the role of the five local food cues in building tourists' trust and loyalty. Our findings demonstrate that tourists judge local foodscapes along with five local food place environment cues and that these judgments drive subsequent trust in a store and local food and behavioral intentions. The findings of the study serve as a starting point for future researchers to test and develop more comprehensive and sophisticated models of local food consumption. 
Second, this study proposed an integrated model and examined the impacts of local foodscapes on trust and loyalty using a cue-consistency theory, resources matching theory, and trust-transfer theory. Prior research has seldom gone beyond the relationship between destination image, emotion, satisfaction, and loyalty except for Chen and Phou's [34] study. Research has shown [24-26] that tourists build trust in retailers and local food through environmental cues about the area where local food is sold. This study addressed the causal process through which consumer trust is formed based on the expectations that tourists experience through the visits to the regions, stores in those regions, and the local food consumed. Using the cognitive resource matching (CRM) hypothesis where messages will reinforce persuasion if there is a match between essential and available cognitive resources [101], this study provided a theoretical framework that informs what is the matching principle or method to make a positive relationship between local foodscapes, as persuasive information cues, and trust in local food store and local food under limited resource allocation conditions.

Lastly, this study explored the mediating roles of trust in a store and local food in the relationship between local foodscapes and loyalty and the casual relationship between trust in a store and local food. In the local food context, trust in local food was found to be an important mediator in the relationship between trust in a store and loyalty. The findings showed that trust in a store and local food are drivers that increase loyalty; tourist loyalty can be increased when local food managers understand the process of local foodscapes $\rightarrow$ trust in a store $\rightarrow$ trust in a local food $\rightarrow$ loyalty.

\subsection{Managerial Implications}

The current study investigated how different local foodscapes influence trust in a store and local food variables that simultaneously influence increasing loyalty. The findings could be of interest to local managers who face establishing a differentiation strategy to increase the patronage of tourists or visitors. Accordingly, local food managers should devise marketing programs that increase trust in a store and local food using various local food environmental cues. Using the resource matching theory [101-103], persuasive local foodscapes communication should be used appropriately and differently depending on the type of store and local food trust. When local food managers try to improve trust in a store, they can focus on maintaining an appealing eco-friendly image and focus on the price/value offering. Local food managers who want to build trust in local food should emphasize the rich history and their eco-friendly image in the communication. COVID-19 has brought about changes in the day-to-day behavior of consumers. There is a lot of apprehension and fear on the part of the consumers to frequent places. This, combined with travel bans imposed by governments and cancellation of airline flights, has resulted in a sharp decline in revenue for the hospitality and the tourism industry. As a result, the tourism industry has experienced "under-crowding". However, with new vaccination measures and the recovery from the global humanitarian crisis, one expects the tourism and hospitality industry to see a sharp increase in patronage as consumers are looking for an opportunity to move out of the confines of their homes. This might result in "overcrowding." It becomes important to develop crowd management strategies to determine appropriate levels of crowd density. A collective effort on the part of communities, service operators, local businesses is warranted to ensure the safety and recovery of the tourism and hospitality industry [104].

First, local foodscapes marketers should focus on building eco-friendly cues or images of the regions where local food is produced since eco-friendly cues have the most powerful influence on trust in a store and local food. Local food marketing success will be increased when efforts are geared toward improving existing attractions and developing new food tourism resources [35]. More specifically, local food production areas should be safe, clean, quiet, and have a comfortable atmosphere and fresh air, and local people should also be sensitive to hygiene. Although trust has been built by consistently providing customers with signals that local foods are clean, safe, and hygienic, if hazardous substances or 
carcinogens are found in some foods, trust in local food and local food store produced in the region may be diminished.

Second, marketers should try to provide value for money because that appears to influence trust in a store. Therefore, local food should be perceived as reasonable, inexpensive, and worthwhile for the cost of the food. Local food marketers can use short food supply chains (SFSCs) that can reduce the number of intermediaries between local food producers and consumers [105]. With the challenges associated with supply-chain delivery and shortages in supply, local foodscapes should focus on sourcing their food (fruits, vegetables, meat, dairy, etc.) from local farms as they have been able to provide a steady stream of fresh goods. These local farms have been able to provide a quick turnaround delivery combined with contactless collection. In addition, with local foods, the retailer always knows where the food comes from, which provides them an assurance in terms of quality combined with the timeliness of the delivery [106]. SFSCs can not only increase the added value of farmers by improving distribution margins but also serve to increase the value for money to consumers by providing fresh food to consumers [107], lowering consumer prices, and buying local foods anywhere, anytime in the country. Local food is also recognized by customers as high-quality food at a low price [108].

Third, in order to specialize local food as a local specialty, marketers should find or develop stories that are interesting, demonstrate tradition and history related to local specialties, and use them in local food stores. Historical stories about local food will help tourists perceive educational, cultural, and novelty values, thereby enhancing the brand value of local foodscapes.

Infrastructure and accessibility were found to have no significant effect on trust in a store and local food. However, marketers should maintain or improve local transportation and personal safety/security along with hospitable people since infrastructures and accessibility are regarded as an important component of the destination image (e.g., [32,33]). Many local restaurants have taken advantage of the changes caused by the pandemic by adapting quickly, offering contactless delivery and dining options. Since local businesses have a smaller staff, they are able to react quicker and adapt to the changes faster. A store where you can buy a variety of local foods at the destination will provide tourists with the convenience of comparative shopping. In addition, since there are many tourists who use private cars or tour buses, providing a large and convenient parking lot will provide the convenience of food shopping. The provision of public transportation for tourists will activate the attraction of food shopping tourists.

Lastly, it is important for the local businesses/stores to work in conjunction with their local health department for protocols and guidance in terms of measures required to keep their business running smoothly. Setting up clear protocols for the local stores and businesses and communicating them to their partners, suppliers, employees, and customers' needs to be established in the new normal caused by the pandemic. Other social distancing guidelines (such as washing hands, maintaining adequate distance, limiting the number of staff in the food preparation area, among others) need to be enforced. This will allow the patrons of the local stores and businesses to feel comfortable and provide the assurances of the necessary checks and balances while visiting these stores [106].

\subsection{Limitations and Future Research Directions}

The findings from the research provide not only a framework for better understanding the purchasing process of local food visitors in local foodscapes but also implications for future research. Firstly, our study used cross-sectional data. Future studies should be conducted at multiple destinations and at different points in time to monitor changes in behavior among tourists and their patronage of these destinations. Dining experiences during and beyond the pandemic need to ensure that the food is hygienic and, at the same time, provides value for money [109]. This study was conducted with respondents from Korea, so it may be difficult to generalize the findings from the study. Therefore, it is recommended that future research needs to be conducted in a variety of cultures, countries, 
and regions. Additionally, future research may want to include other cues/dimensions to address local foodscapes, such as service quality measures, among others. Finally, it would be desirable for future studies to focus on specific regions that have been successful with local food and analyze the cues/dimensions that have made them successful.

Author Contributions: Conceptualization, J.-J.Y., Y.-K.L. and R.I.; methodology, J.-J.Y., Y.-K.L. and R.I.; software, J.-J.Y., Y.-K.L. and R.I.; validation, J.-J.Y., Y.-K.L. and R.I.; formal analysis, J.-J.Y., Y.-K.L. and R.I.; investigation, J.-J.Y. and Y.-K.L.; data curation, J.-J.Y., Y.-K.L. and R.I.; writing-original draft preparation, J.-J.Y., Y.-K.L. and R.I.; writing-review and editing, J.-J.Y., Y.-K.L. and R.I.; supervision, J.-J.Y., Y.-K.L. and R.I.; project administration, J.-J.Y., Y.-K.L. and R.I. All authors have read and agreed to the published version of the manuscript.

Funding: This research was funded by the Graduate School Specialization Project of Sejong University.

Institutional Review Board Statement: Not applicable.

Informed Consent Statement: Not applicable.

Data Availability Statement: Not applicable.

Conflicts of Interest: The authors declare no conflict of interest.

\section{References}

1. Mak, A.H.; Lumbers, M.; Eves, A.; Chang, R.C. Factors influencing tourist food consumption. Int. J. Hosp. Manag. 2012, 31, 928-936. [CrossRef]

2. Björk, P.; Kauppinen-Räisänen, H. Destination foodscape: A stage for travelers' food experience. Tour. Manag. 2019, 71, 466-475. [CrossRef]

3. Kim, Y.G.; Eves, A.; Scarles, C. Building a model of local food consumption on trips and holidays: A grounded theory approach. Int. J. Hosp. Manag. 2009, 28, 423-431. [CrossRef]

4. Torres, R. Toward a better understanding of tourism and agriculture linkages in the Yucatan: Tourist food consumption and preferences. Tour. Geogr. 2002, 4, 282-306. [CrossRef]

5. Chang, R.C.; Kivela, J.; Mak, A.H. Attributes that influence the evaluation of travel dining experience: When East meets West. Tour. Manag. 2011, 32, 307-316. [CrossRef]

6. Kivela, J.; Crotts, J.C. Tourism and gastronomy: Gastronomy's influence on how tourists experience a destination. J. Hosp. Tour. Res. 2006, 30, 354-377. [CrossRef]

7. Kivela, J.J.; Crotts, J.C. Understanding travelers' experiences of gastronomy through etymology and narration. J. Hosp. Tour. Res. 2009, 33, 161-192. [CrossRef]

8. Kim, S.; Park, E.; Lamb, D. Extraordinary or ordinary? Food tourism motivations of Japanese domestic noodle tourists. Tour. Manag. Perspect. 2019, 29, 176-186. [CrossRef]

9. Lee, Y.-K.; Lee, C.K.; Lee, S.K.; Babin, B.J. Festivalscapes and patrons' emotions, satisfaction, and loyalty. J. Bus. Res. 2008, 61, 56-64. [CrossRef]

10. Choe, J.Y.J.; Kim, S.S. Effects of tourists' local food consumption value on attitude, food destination image, and behavioral intention. Int. J. Hosp. Manag. 2018, 71, 1-10. [CrossRef]

11. Tapachai, N.; Waryszak, R. An examination of the role of beneficial image in tourist destination selection. J. Travel Res. 2000, 39, 37-44. [CrossRef]

12. Al-Ansi, A.; Han, H. Role of halal-friendly destination performances, value, satisfaction, and trust in generating destination image and loyalty. J. Destin. Mark. Manag. 2019, 13, 51-60. [CrossRef]

13. Everett, S.; Aitchison, C. The role of food tourism in sustaining regional identity: A case study of Cornwall, South West England. J. Sustain. Tour. 2008, 16, 150-167. [CrossRef]

14. Hsu, F.C.; Scott, N. Food experience, place attachment, destination image and the role of food-related personality traits. J. Hosp . Tour. Manag. 2020, 44, 79-87. [CrossRef]

15. World Food Travel Association. 2021. Available online: https://worldfoodtravel.org/ (accessed on 15 December 2022).

16. Kang, S.J.; Doh, K.L.; Jo, L.H. A study on market segmentation of foreign visitors to vitalize localfood tourism: By food related behaviors during a trip. Korean J. Tour. Res. 2014, 29, 177-197.

17. Sidali, K.L.; Kastenholz, E.; Bianchi, R. Food tourism, niche markets and products in rural tourism: Combining the intimacy model and the experience economy as a rural development strategy. J. Sustain. Tour. 2015, 23, 1179-1197. [CrossRef]

18. Bessière, J. Local development and heritage: Traditional food and cuisine as tourist attractions in rural areas. Sociol. Rural. 1998, 38, 21-34. [CrossRef]

19. Chang, R.C.; Kivela, J.; Mak, A. Food preferences of Chinese tourists. Ann. Tour. Res. 2010, 37, 989-1011. [CrossRef]

20. Henderson, J.C. Food tourism reviewed. Br. Food J. 2009, 111, 317-326. [CrossRef] 
21. Rong-Da Liang, A.; Chen, S.C.; Tung, W.; Hu, C.C. The influence of food expenditure on tourist response to festival tourism: Expenditure perspective. Int. J. Hosp. Tour. Adm. 2013, 14, 377-397. [CrossRef]

22. Garmaroudi, S.A.; King, C.; Lu, L. Social servicescape's impact on customer perceptions of the hospitality brand-The role of branded social cues. Int. J. Hosp. Manag. 2021, 93, 102774. [CrossRef]

23. Strub, P.J.; Priest, T.B. Two patterns of establishing trust: The marijuana user. Sociol. Focus 1976, 9, 399-411. [CrossRef]

24. Lee, Y.-K.; Kim, S.; Lee, C.K.; Kim, S.H. The impact of a mega event on visitors' attitude toward hosting destination: Using trust transfer theory. J. Travel Tour. Mark. 2014, 31, 507-521. [CrossRef]

25. Deng, Q.; Li, M. A model of event-destination image transfer. J. Travel Res. 2014, 53, 69-82. [CrossRef]

26. McKnight, D.H.; Cummings, L.L.; Chervany, N.L. Initial trust formation in new organizational relationships. Acad. Manag. Rev. 1998, 23, 473-490. [CrossRef]

27. Weatherell, C.; Tregear, A.; Allinson, J. In search of the concerned consumer: UK public perceptions of food, farming and buying local. J. Rural Stud. 2003, 19, 233-244. [CrossRef]

28. Hinrichs, C.C. The practice and politics of food system localization. J. Rural Stud. 2003, 19, 33-45. [CrossRef]

29. Ryu, K.; Jang, S. DINESCAPE: A scale for customers' perception of dining environments. J. Foodserv. Bus. Res. 2008, 11, 2-22. [CrossRef]

30. Bitner, M.J. Servicescapes: The impact of physical surroundings on customers and employees. J. Mark. 1992, 56, 57-71. [CrossRef]

31. Fuentes, C.; Bäckström, K.; Svingstedt, A. Smartphones and the reconfiguration of retailscapes: Stores, shopping, and digitalization. J. Retail. Consum. Serv. 2017, 39, 270-278. [CrossRef]

32. Chi, C.G.Q.; Qu, H. Examining the structural relationships of destination image, tourist satisfaction and destination loyalty: An integrated approach. Tour. Manag. 2008, 29, 624-636. [CrossRef]

33. Gómez, M.; Lopez, C.; Molina, A. A model of tourism destination brand equity: The case of wine tourism destinations in Spain. Tour. Manag. 2015, 51, 210-222. [CrossRef]

34. Chen, C.F.; Phou, S. A closer look at destination: Image, personality, relationship and loyalty. Tour. Manag. 2013, 36, 269-278. [CrossRef]

35. Lee, C.K.; Lee, Y.-K.; Lee, B. Korea's destination image formed by the 2002 World Cup. Ann. Tour. Res. 2005, 32, 839-858. [CrossRef]

36. Temperini, V.; Limbu, Y.; Jayachandran, C. Consumers' trust in food quality and willingness to pay more for national parks' brands: Preliminary evidence from Italy. J. Int. Food Agribus. Mark. 2017, 29, 120-138. [CrossRef]

37. Barham, E. Translating terroir: The global challenge of French AOC labeling. J. Rural Stud. 2003, 19, 127-138. [CrossRef]

38. Van Ittersum, K.; Candel, M.J.; Meulenberg, M.T. The influence of the image of a product's region of origin on product evaluation. J. Bus. Res. 2003, 56, 215-226. [CrossRef]

39. Bessiere, J.; Tibere, L. Traditional food and tourism: French tourist experience and food heritage in rural spaces. J. Sci. Food Agric. 2013, 93, 3420-3425. [CrossRef]

40. Hobsbawm, E.J. Introduction: Inventing traditions. In The Invention of Tradition; Hobsbawm, E.J., Ranger, T., Eds.; Cambridge University Press: Cambridge, UK, 1983.

41. Tellström, R.; Gustafsson, I.B.; Mossberg, L. Consuming heritage: The use of local food culture in branding. Place Brand. 2006, 2, 130-143. [CrossRef]

42. Gragnani, M. The EU regulation $1151 / 2012$ on quality schemes for agricultural products and foodstuffs. Eur. Food Feed Law Rev. 2013, 8, 376-385. Available online: https:/ / www.jstor.org/stable/24325986 (accessed on 15 December 2022).

43. Chambers, S.; Lobb, A.; Butler, L.; Harvey, K.; Traill, W.B. Local, national and imported foods: A qualitative study. Appetite 2007, 49, 208-213. [CrossRef]

44. Fandos, C.; Flavián, C. Intrinsic and extrinsic quality attributes, loyalty and buying intention: An analysis for a PDO product. Br. Food J. 2006, 108, 646-662. [CrossRef]

45. Åsebø, K.; Jervell, A.M.; Lieblein, G.; Svennerud, M.; Francis, C. Farmer and consumer attitudes at farmers markets in Norway. J. Sustain. Agric. 2007, 30, 67-93. [CrossRef]

46. Risku-Norja, H.; Hietala, R.; Virtanen, H.; Ketomäki, H.; Helenius, J. Localisation of primary food production in Finland: Production potential and environmental impacts of food consumption patterns. Agric. Food Sci. 2008, 17, 127-145. [CrossRef]

47. Connelly, S.; Beckie, M. The dilemma of scaling up local food initiatives: Is social infrastructure the essential ingredient? Can. Food Stud. 2016, 3, 49-69. [CrossRef]

48. Pilcher, J.M. Culinary infrastructure: How facilities and technologies create value and meaning around food. Glob. Food Hist. 2016, 2, 105-131. [CrossRef]

49. Geurs, K.; Zondag, B.; De Jong, G.; de Bok, M. Accessibility appraisal of land-use/transport policy strategies: More than just adding up travel-time savings. Transp. Res. Part D Transp. Environ. 2010, 15, 382-393. [CrossRef]

50. Coveney, J.; O'Dwyer, L.A. Effects of mobility and location on food access. Health Place 2009, 15, 45-55. [CrossRef]

51. Larsen, K.; Gilliland, J. Mapping the evolution of 'food deserts' in a Canadian city: Supermarket accessibility in London, Ontario, 1961-2005. Int. J. Health Geogr. 2008, 7, 16. [CrossRef] [PubMed]

52. Su, L.; Hsu, M.K.; Swanson, S. The effect of tourist relationship perception on destination loyalty at a world heritage site in China: The mediating role of overall destination satisfaction and trust. J. Hosp. Tour. Res. 2017, 41, 180-210. [CrossRef] 
53. Macready, A.L.; Hieke, S.; Klimczuk-Kochańska, M.; Szumiał, S.; Vranken, L.; Grunert, K.G. Consumer trust in the food value chain and its impact on consumer confidence: A model for assessing consumer trust and evidence from a 5-country study in Europe. Food Policy 2020, 92, 101880. [CrossRef]

54. Lichtenstein, D.R.; Ridgway, N.M.; Netemeyer, R.G. Price perceptions and consumer shopping behavior: A field study. J. Mark. Res. 1993, 30, 234-245. [CrossRef]

55. Han, H.; Hyun, S.S. Customer retention in the medical tourism industry: Impact of quality, satisfaction, trust, and price reasonableness. Tour. Manag. 2015, 46, 20-29. [CrossRef]

56. Gschwandtner, A. The organic food premium: A local assessment in the UK. Int. J. Econ. Bus. 2018, 25, 313-338. [CrossRef]

57. Bruschi, V.; Shershneva, K.; Dolgopolova, I.; Canavari, M.; Teuber, R. Consumer perception of organic food in emerging markets: Evidence from Saint Petersburg, Russia. Agribusiness 2015, 31, 414-432. [CrossRef]

58. Żakowska-Biemans, S. Polish consumer food choices and beliefs about organic food. Br. Food J. 2011, 113, 122-137. [CrossRef]

59. Trivette, S.A. Invoices on scraps of paper: Trust and reciprocity in local food systems. Agric. Hum. Values 2017, 34, 529-542. [CrossRef]

60. Fonte, M. Knowledge, food and place. A way of producing, a way of knowing. Sociol. Rural. 2008, 48, 200-222. [CrossRef]

61. Sims, R. Food, place and authenticity: Local food and the sustainable tourism experience. J. Sustain. Tour. 2009, 17, 321-336. [CrossRef]

62. Loureiro, S.M.C.; González, F.J.M. The importance of quality, satisfaction, trust, and image in relation to rural tourist loyalty. J. Travel Tour. Mark. 2008, 25, 117-136. [CrossRef]

63. Sirdeshmukh, D.; Singh, J.; Sabol, B. Consumer trust, value, and loyalty in relational exchanges. J. Mark. 2002, 66, 15-37. [CrossRef]

64. Roy, H.; Hall, C.M.; Ballantine, P.W. Trust in local food networks: The role of trust among tourism stakeholders and their impacts in purchasing decisions. J. Destin. Mark. Manag. 2017, 6, 309-317. [CrossRef]

65. Zhang, L.; Xu, Y.; Oosterveer, P.; Mol, A.P. Consumer trust in different food provisioning schemes: Evidence from Beijing, China. J. Clean. Prod. 2016, 134, 269-279. [CrossRef]

66. Kjaernes, U.; Harvey, M.; Warde, A. Trust in Food: A Comparative and Institutional Analysis; Palgrave MacMillan: Houndmills, UK, 2007.

67. Sodano, V.; Hingley, M.; Lindgreen, A. The usefulness of social capital in assessing the welfare effects of private and third-party certification food safety policy standards: Trust and networks. Br. Food J. 2008, 110, 493-513. [CrossRef]

68. Konuk, F.A. Trust transfer from manufacturer to private label brand: The moderating role of grocery store format. J. Retail. Consum. Serv. 2020, 54, 101955. [CrossRef]

69. Doney, P.M.; Cannon, J.P. An examination of the nature of trust in buyer-seller relationships. J. Mark. 1997, 61, 35-51. [CrossRef]

70. Xiao, L.; Fu, B.; Liu, W. Understanding consumer repurchase intention on O2O platforms: An integrated model of network externalities and trust transfer theory. Serv. Bus. 2018, 12, 731-756. [CrossRef]

71. Liu, L.; Lee, M.K.; Liu, R.; Chen, J. Trust transfer in social media brand communities: The role of consumer engagement. Int. J. Inf. Manag. 2018, 41,1-13. [CrossRef]

72. Palmatier, R.W.; Dant, R.P.; Grewal, D.; Evans, K.R. Factors influencing the effectiveness of relationship marketing: A metaanalysis. J. Mark. 2006, 70, 136-153. [CrossRef]

73. Yamagishi, T.; Akutsu, S.; Cho, K.; Inoue, Y.; Li, Y.; Matsumoto, Y. Two-component model of general trust: Predicting behavioral trust from attitudinal trust. Soc. Cogn. 2015, 33, 436-458. [CrossRef]

74. Anderson, E.; Weitz, B. Determinants of continuity in conventional industrial channel dyads. Mark. Sci. 1989, 8, 310-323. [CrossRef]

75. Schurr, P.H.; Ozanne, J.L. Influences on exchange processes: Buyers' preconceptions of a seller's trustworthiness and bargaining toughness. J. Consum. Res. 1985, 11, 939-953. [CrossRef]

76. Agustin, C.; Singh, J. Curvilinear effects of consumer loyalty determinants in relational exchanges. J. Mark. Res. 2005, 42, 96-108. [CrossRef]

77. Delgado-Ballester, E.; Munuera-Aleman, J.L.; Yague-Guillen, M.J. Development and validation of a brand trust scale. Int. J. Mark. Res. 2003, 45, 35-54. [CrossRef]

78. Konuk, F.A. The impact of retailer innovativeness and food healthiness on store prestige, store trust and store loyalty. Food Res. Int. 2019, 116, 724-730. [CrossRef]

79. Chaudhuri, A.; Holbrook, M.B. The chain of effects from brand trust and brand affect to brand performance: The role of brand loyalty. J. Mark. 2001, 65, 81-93. [CrossRef]

80. Dillman, R.O. Infusion reactions associated with the therapeutic use of monoclonal antibodies in the treatment of malignancy. Cancer Metastasis Rev. 1999, 18, 465-471. [CrossRef]

81. Bentler, P.M.; Chou, C.P. Practical issues in structural modeling. Sociol. Methods Res. 1987, 16, 78-117. [CrossRef]

82. Bollen, K.A. A new incremental fit index for general structural equation models. Sociol. Methods Res. 1989, 17, 303-316. [CrossRef]

83. Hair, J.F.; Black, W.C.; Babin, B.J.; Anderson, R.E.; Tatham, R. Uppersaddle River. Multivariate Data Analysis, 6th ed; Prentice-Hall International: Hoboken, NJ, USA, 2006.

84. Xie, J.; Gao, Z.; Swisher, M.; Zhao, X. Consumers' preferences for fresh broccolis: Interactive effects between country of origin and organic labels. Agric. Econ. 2016, 47, 181-191. [CrossRef] 
85. Kim, S.; Lee, Y.-K.; Lee, C.K. The moderating effect of place attachment on the relationship between festival quality and behavioral intentions. Asia Pac. J. Tour. Res. 2017, 22, 49-63. [CrossRef]

86. Lee, Y.-K.; Pei, F.; Ryu, K.S.; Choi, S. Why the tripartite relationship of place attachment, loyalty, and pro-environmental behaviour matter? Asia Pac. J. Tour. Res. 2019, 24, 250-267. [CrossRef]

87. Henseler, J.; Hubona, G.; Ray, P.A. Using PLS path modeling in new technology research: Updated guidelines. Ind. Manag. Data Syst. 2016, 116, 2-20. [CrossRef]

88. Kim, E.J.; Kim, S.H.; Lee, Y.K. The effects of brand hearsay on brand trust and brand attitudes. J. Hosp. Mark. Manag. 2019, 28, 765-784. [CrossRef]

89. Schmider, E.; Ziegler, M.; Danay, E.; Beyer, L.; Bühner, M. Is it really robust? Methodology 2010, 6, 147-151. [CrossRef]

90. Kang, T.W.; Sinha, P.N.; Park, C.I.; Lee, Y.-K. Exploring the intra entrepreneurship-employee engagement-creativity linkage and the diverse effects of gender and marital status. Front. Psychol. 2021, 12, 736914. [CrossRef]

91. Podsakoff, P.M.; MacKenzie, S.B.; Podsakoff, N.P. Sources of method bias in social science research and recommendations on how to control it. Annu. Rev. Psychol. 2012, 63, 539-569. [CrossRef]

92. Kock, N. Common method bias in PLS-SEM: A full collinearity assessment approach. Int. J. E-Collab. 2015, 11, 1-10. [CrossRef]

93. Hair, J.F.; Hult, G.T.M.; Ringle, C.M.; Sarstedt, M.; Thiele, K.O. Mirror, mirror on the wall: A comparative evaluation of composite-based structural equation modeling methods. J. Acad. Mark. Sci. 2017, 45, 616-632. [CrossRef]

94. Lee, Y.-E.; Lee, Y.-K. Impacts of relative advantage of fast food restaurant's O2O service and consumer involvement on consumer engagement, and store loyalty: Focused on MZ generations in non-tact consumption era. Korean J. Franch. Manag. 2020, 11, 41-51. [CrossRef]

95. Hwang, J.K.; Kim, E.-J.; Lee, S.-M.; Lee, Y.-K. Impact of susceptibility to global consumer culture on commitment and loyalty in botanic cosmetic brands. Sustainability 2021, 13, 892. [CrossRef]

96. Hair, J.F., Jr.; Sarstedt, M.; Hopkins, L.; Kuppelwieser, V.G. Partial least squares structural equation modeling (PLS-SEM): An emerging tool in business research. Eur. Bus. Rev. 2014, 26, 106-121. [CrossRef]

97. Hair, J.F.; Risher, J.J.; Sarstedt, M.; Ringle, C.M. When to use and how to report the results of PLS-SEM. Eur. Bus. Rev. 2019, 31, 2-24. [CrossRef]

98. Sarstedt, M.; Cheah, J.H. Partial least squares structural equation modeling using SmartPLS: A software review. J. Mark. Anal. 2019, 7, 196-202. [CrossRef]

99. Chin, W.W. The partial least squares approach to structural equation modeling. Mod. Methods Bus. Res. 1998, 295, $295-336$.

100. Hu, L.T.; Bentler, P.M. Fit indices in covariance structure modeling: Sensitivity to underparameterized model misspecification. Psychol. Methods 1998, 3, 424-453. [CrossRef]

101. Keller, P.A.; Block, L.G. Vividness effects: A resource-matching perspective. J. Consum. Res. 1997, 24, 295-304. [CrossRef]

102. Coulter, K.S.; Punja, G.N. The effects of cognitive resource requirements, availability, and argument quality on brand attitudes: A melding of elaboration likelihood and cognitive resource matching theories. J. Advert. 2004, 33, 53-64. [CrossRef]

103. Song, M.; Noone, B.M.; Han, R.J. An examination of the role of booking lead time in consumers' reactions to online scarcity messages. Int. J. Hosp. Manag. 2019, 77, 483-491. [CrossRef]

104. Lim, W.M. Toward an agency and reactance theory of crowding: Insights from COVID-19 and the tourism industry. J. Consum. Behav. 2021, 20, 1690-1694. [CrossRef]

105. Chiffoleau, Y.; Millet-Amrani, S.; Rossi, A.; Rivera-Ferre, M.G.; Merino, P.L. The participatory construction of new economic models in short food supply chains. J. Rural Stud. 2019, 68, 182-190. [CrossRef]

106. Covid-19: How is the Foodservice Industry Coping? Available online: https://hospitalityinsights.ehl.edu/covid-19-foodserviceindustry (accessed on 29 January 2022).

107. Jarzębowski, S.; Bourlakis, M.; Bezat-Jarzębowska, A. Short food supply chains (SFSC) as local and sustainable systems. Sustainability 2020, 12, 4715. [CrossRef]

108. González-Azcárate, M.; Maceín, J.L.C.; Bardají, I. Why buying directly from producers is a valuable choice? Expanding the scope of short food supply chains in Spain. Sustain. Prod. Consum. 2021, 26, 911-920. [CrossRef]

109. Lim, W.M.; Aggarwal, A.; Dandotiya, R. Marketing luxury services beyond affluence in the new normal: Insights from fine dining during the coronavirus pandemic. J. Retail. Consum. Serv. 2022, 102936. [CrossRef] 